\title{
THE STUDENTS' PERCEPTION ON THE USE OF E-BOOK AS LEARNING SOURCES AT THE SIXTH SEMESTER STUDENTS OF ENGLISH EDUCATION STUDY PROGRAM OF BATURAJA UNIVERSITY
}

\author{
${ }^{1}$ Henny Yulia, ${ }^{2}$ Shofiyatul Huriyah \\ 1hennyyulia78@gmail.com, ${ }^{2}$ shofiyatulhuriyah@gmail.com
}

\section{BATURAJA UNIVERSITY}

\begin{abstract}
The purpose of this study was to find out the students perceptions on the use of E-book as learning sources at the sixth semester students of English Education Study Program of Baturaja University.The population of the research was 22 students majoring in English study program. The writer took 22 students by using total sample. This study used descriptive qualitative method and the data were collected by using questionnaire. The questionnaire consists of 20 items in the form of five likert scale. The result of the study showed that $92.90 \%$ students had positive response and support E book as learning sources. It indicated that E-book was easy to use. By using E- book both students and lecturers can improve their creativity.
\end{abstract}

Key word : perception, E- book, learning sources.

Abstrak: Penelitian ini bertujuan untuk menemukan persepsi siswa dalam menggunakan E- book sebagai sumber belajar pada mahasiswa program studi pendidikan bahasa inggris semester enam Universitas Baturaja. Populasi penelitian yaitu 22 siswa dan diambil semuanya untuk dijadikan sampel dengan metode total sampling. Penelitian ini menggunakan metode dekriptif kualitatif. Data dikumpulkan dengan menggunakan angket. Angket terdiri dari 20 soal dalam bentuk skala likert. Hasil penelitian menunjukkan bahwa $92.90 \%$ siswa memiliki respon positif dan mendukung E-book sebagai sumber belajar. Hal itu menunjukkan bahwa E- book mudah di gunakan. Dengan menggunakan E- book mahasiswa dan dosen dapat meningkatkan kreatifitasnya masing- masing.

Kata kunci : persepsi, E-book, sumber belajar.

\section{INTRODUCTION}

The goal of education is to the most important thing to be reach in achieving academic success. To support this, cooperation is needed from educators and students. Learning systems began to use digital tool as one of the effects of technological advancement. Since the beginning of 1990 there had been so many progress in educational media. This, further allow lecturers and students to use E- book as learning facilities and resources. Wright et, al (2013) stated that the advancement of

${ }^{1) 2)}$ Dosen Universitas Baturaja 
technology have led to the use of electronic reading system for digital text. Reading in a digital type report to be more enjoyable. Larson (2009) also expressed the same opinion with wright. $\mathrm{He}$ argued that students activities are dominated by electronic devices.This condition support school to start using E-book to make learning process more interesting.

E-book offers so many advantages to be used. Hasbiyati and Khusna (2017) said that E-book can increase students' interest in learning.This can strengthen the statement that by using E-book students' interest can become better. When compared to the traditional books, E- books offer numerous advantages. According to Koh and Hearing (2013), E- books have a number of advantages over traditional printed books. They are simple to us. There is no need to go to the library. Second, they are easy to search for the topics and they can be easily access at anywhere and anytime. Furthermore, display is better, cheaper and save space deviation.

Mulholland et al. (2014), defined an E-book as a digitized version of a paper based book than can be read on compatible devices. Wexelbaoum et al. (2011), also said that an e book is a type of electronic text that is available in digitally encoded format that can be read on computer or other electronic devices. E-book is available in specialized often proprietary file format that must be read using specialized software.

According to Adeyinka et al. (2018), the term E-book refers to a variety of digital book or an edition of printed book. An E- book is a book length, digital publication that contains text, image or both that can be read on computers or other electronic devices.

According to Hadaya et al. (2018), while today students are familiar with many technologies including hand held devices they do not fully use technology into their learning activities. In fact, many students still prefer to read traditional printed books rather than electronic books. Furthermore, Chen et al. (2012) discovered that most college students have positive attitudes toward E-books and prefer reading E-books to paper materials. Although they stated that E-books have some flaws, such as being bad for health (e.g., the eyes), being easy to lose data if you forget to back up, and so on. However, these issues will not impede the development of E-books because they offer additional benefits such as watching videos, searching for words, and being less expensive in the long run. The successful research and development of this technology can be attributed to the advancement of the E-book. Over the next few years, people's lives will become more integrated with electronic products. 
Using an E-book in the learning process can be beneficial because students can find additional information about the materials. Students can find the materials on their own, or the lecturer can recommend E-books that can be used as references in their studies. Lecturers will spend less time in the classroom explaining materials and will assign more assignments for students to apply their understanding of the materials they have already read from an E-book. Students can save the materials they will learn in class on their laptops or smart phones. It may make students feel more enjoyable, but it may also have an impact on the learning process because students will only focus on the E-book rather than interacting with lecturers in the classroom, they use laptops or smart phones. According to Ningsih (2016), for some reasons E-books can be a good way to improve students' classroom learning, but for those who do not have smart phones or laptops, it will be more difficult because they will need to go to public internet then save it in portable disk or even print it out so that they can use it later in the classroom.

In addition, according to Walters (2013), there are some advantages of using E-books, such as: E-books can be accessed at any time and from any location where there is an internet connection, multiple books can be stored on a single device, and E-books can be hyperlinked internally and from one document to another. The text can be copied and pasted into an e-book. Furthermore, Majid et al. (2019) stated that E-books have advantages such as the ability to store many books on a single device, the convenience of using them anytime and anywhere, the ease of downloading (no need to go to a library), the portability, the ease of searching and sharing, the ease of cutting and pasting, and the lower cost of purchase.

Beside its advantages, E- books also have some disadvantages.According to Walter (2013), there are some drawbacks to E-books, such as E-books are only useful if you have a device to read them on. The reader device's battery life is limited and must be charged. The reader device may experience technical difficulties, preventing the user from accessing the Ebook. Some people experience eye strain after reading for extended periods of time.According to Majid et al. (2019), some disadvantages of E-books include: eye strain, poor quality of scanned E-books, and small screen size of smartphones.

Based on the researcher's preobservation through informal interviews with Baturaja University students, particularly those in the English Education Study Program who used E-books in their learning process.They said that some lecturers used electronic books as learning resources. The lecturers distributed E- 
books via Whatsapp group. It was very accessible because students could read the material on their phone or computer.

Based on the explanation above, the researcher was curious about students' perception on the use of E-books as learning resources. The study investigated Sixth Semester Students' Perceptions of Using E-books as Learning Sources at Baturaja University.

\section{METHODOLOGY}

The descriptive qualitative research method was used by the researcher in this study. It was applied in order to find out the students perceptions on the use of E- book as learning sources.

\section{Population and sample}

The population was the sixth semester students majoring in English education study program at Baturaja University.The writer employed total sampling in this study. Total sampling, according to Sugiyono (2016), is a technique in which the number of samples is the same as the population size.

\section{Technique for Collecting Data}

In this study, the questionnaire was used to collect data from respondents and to assess students' perceptions of using E-books as a learning resource. The questionnaire was divided into two sections: student demographics and student perceptions. To collect information about students' perceptions, the researcher adapted a questionnaire developed by Ningsih (2016). The questionnaire's indicators are the use of E-books in the learning process, the benefits of E-books, and the drawbacks of E-books. The students' perception scale included five responses: "Strongly disagree,""Disagree,""Neutral/Undecided," "Agree," and "Strongly Agree." It included 20 items designed to reveal the students' perceptions on the use of E-books as learnng resources. Participants were asked to select from a list of options in the questionnaire.

\section{Technique for Analyzing Data}

To analyze the data obtained from the questionnaire the researcher used formula from Sudijono (2010).

\section{$\mathbf{P}=\mathbf{f} / \mathbf{1 0 0}$}

To get percentage of students' score distribution of the questionnaire, the writer used:

Table 1

The Criteria of Scores Interpretation Based on Interval

\begin{tabular}{|l|l|l|}
\hline No & Interval Score & Criteria \\
\hline 1. & $0 \%-20 \%$ & Strongly Disagree \\
\hline 2. & $21 \%-40 \%$ & Disagree \\
\hline
\end{tabular}


The Students' Perception On The Use Of E-Book As Learning Sources At The Sixth Semester Students Of English Education Study Program Of Baturaja University (Henny Yulia dan Shofiyatul Huriyah)

\begin{tabular}{|l|l|l|}
\hline 3. & $41 \%-60 \%$ & Neutral/Undecided \\
\hline 4. & $61 \%-80 \%$ & Agree \\
\hline 5. & $81 \%-100 \%$ & Strongly Agree \\
\hline
\end{tabular}

Source : Riduwan \& Sunarto (2017)

\section{RESULT AND DISCUSSION}

\section{Result}

The Result of Students' Perception in Each Indicator of Questionnaire the Use of E-Book in Learning Process

From the result of finding, it was found that an overwhelming number of students had the use of E-book in learning process. It could be seen from the table 6 , the result of questionnaire (the use of e-book in learning process) in statement $1,2,3,4$, 5,6 , and 7 .

1) For the statement number 1 (E-book can help me improve how to use technology for educational purposes namely in learning) there were 14 students $(63,6 \%)$ answered agree with that statement. 5 students $(22,7 \%)$ answered strongly agree. 2 students $(9,10 \%)$ answered disgaree. However, only 1 student $(4,6 \%)$ answered neutral with that statement.

2) Moreover for the item number 2 (E-book can widen my knowledge about materials that I want to learn) 15 students $(68,1 \%)$ answered that they agree with that statement. 5 students (22\%) answered strongly agree and 2 students $(9,09 \%)$ answered neutral

3) For item number 3 (I understand more if lecturers use E-book as educational tools in learning process, 20 students $(90,8 \%)$ answered agree, 1 student $(4,6 \%)$ answered strongly agree and 1 student $(4,6 \%)$ answered neutral with that statement.

4) For item 4, 20 students $(90,8 \%)$ answered agree that E-book can help them to improve their knowledge during learning process, 1 student $(4,6 \%)$ answered strongly agree and 1 student $(4,6 \%)$ answered neutral.

5) Beside that, for item number 5, 12 students $(54,5 \%)$ agreed that the use of Ebook as a medium of learning is the best ways to make students study on their own while 8 students $(36,4 \%)$ answered strongly agree and 2 students $(9,09 \%)$ answered neutral.

6) For item number 6, (I like when lecturers use E-book during learning process) 16 students $(72,7 \%)$ said that they were agree, 5 students $(22,7 \%)$ answered strongly agree and 1 student $(4,54 \%)$ answered neutral.

7) As well as for item number 7, the majority, 12 students (54,5\%) answered agree for the statement (I find E-book helpful for me in searching material by my own), while 9 students $(40,9 \%)$ were 
strongly agree and 1 student $(4,54 \%)$ answered neutral.

Based on finding in this research about students perception on the use of Ebook in learning process, the researcher found about $92.90 \%$ of the students agree and strongly agree, $5.3 \%$ of the students neutral and $1.30 \%$ of the students disagree toward the use of E-book in learning process.

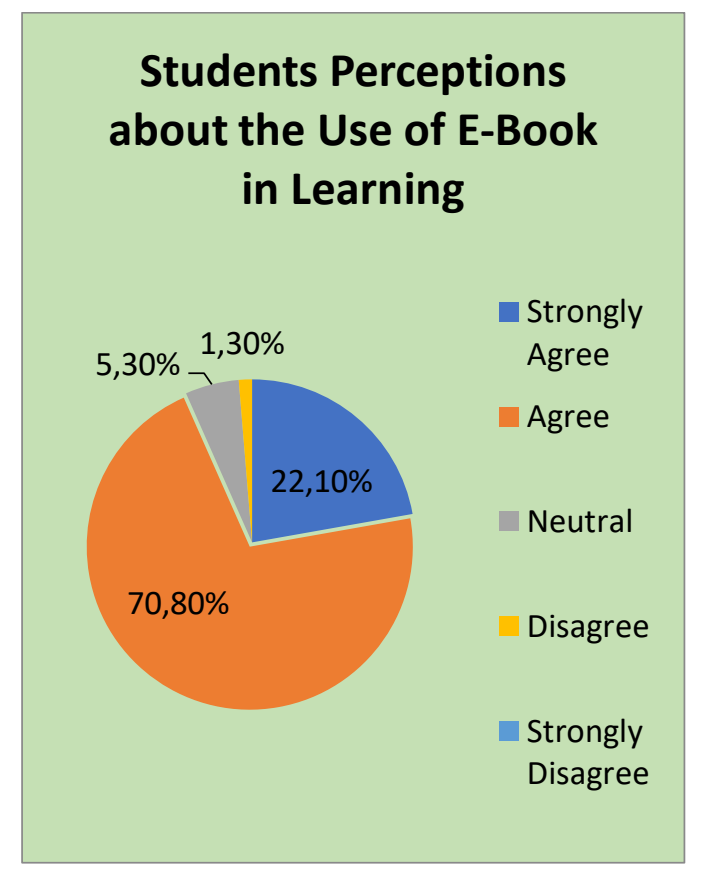

2. The Result of Questionnaire about The Advantages of E- Book

From the research finding, it was found that an overwhelming number of students had the advantages of E-book. It could be seen from the table 7 , the result of questionnaire (the advantages of e-book) in statement 8, 9, 10, 11,12, 13, 14and 15 .

1) First, in the statement (8), the frequency 12 students $(54,5 \%)$ of students answered strongly agree, 5 students $(22,7 \%)$ answered agree, 4 students $(18,2 \%)$ answered neutral, and 1 students $(4,6 \%)$ answered disagree.

2) Furthermore, for item number 9, 10 students (45\%) were strongly agreed, 8 students $(36,3 \%)$ answered agree, 3 students (14\%) answered neutral and 1 students $(4,6 \%)$ answered disagree that E-book can be used anytime and anywhere.

3) For item 10, 10 students (59\%) agreed that E-book provides many resources just in one click. While 5 students $(22,7 \%)$ answered strongly agree, and 4 students $(18,2)$ answered neutral.

4) As for the results of item 11, a large number respondents $(72,7 \%)$ agreed that E-book is easy to carry in the classroom. 4 students $(18,2 \%)$ answered strongly agree and 4 students $(9,02 \%)$ answered neutral.

5) As for the results of item 12, a large number of respondents $(50 \%)$ answered agree that E- book is easy to carry in the classroom. 7 students (32 $\%$ ) ansered strongly agree and 4 students (18\%) answered neutral.

6) Concerning item 13, 13 students (59\%) answered strongly agree. 5 students stated that they were agree $(22,7 \%)$ and 2 students $(9,09 \%)$ answered disagree 
with this statement. While there is equality frequency $(6,2 \%)$ of students who answered neutral and strongly disagree

7) Furthermore, for item 14, a high proportion of the 11 students (50\%) answered agree that E-book has many features besides textbook, such as audio, video, and animation. 7 students $(31,8 \%)$ answered strongly agreed with this statement and 3 students $(13,6 \%)$ answered neutral.

8) The students report show mixed responses on the item 15 on statement by using E-book as learning sources. They said that they can bring multiple books in their device. 10 students (45\%) answered Strongly agree and 8 students (36,3\%) answered agreed with this statement. While there is equality frequency $(9,10 \%)$ of students who answered neutral and disagree.

Based on finding in this research about students' perception towards the advantages of E-book, the researcher found about $78.13 \%$ of the students were agree and strongly agree with the statements, $13,68 \%$ were neutral and $6.13 \%$ of the students were disagree. The last, $2.06 \%$ of the students were strongly disagree toward the advantages of E-book.

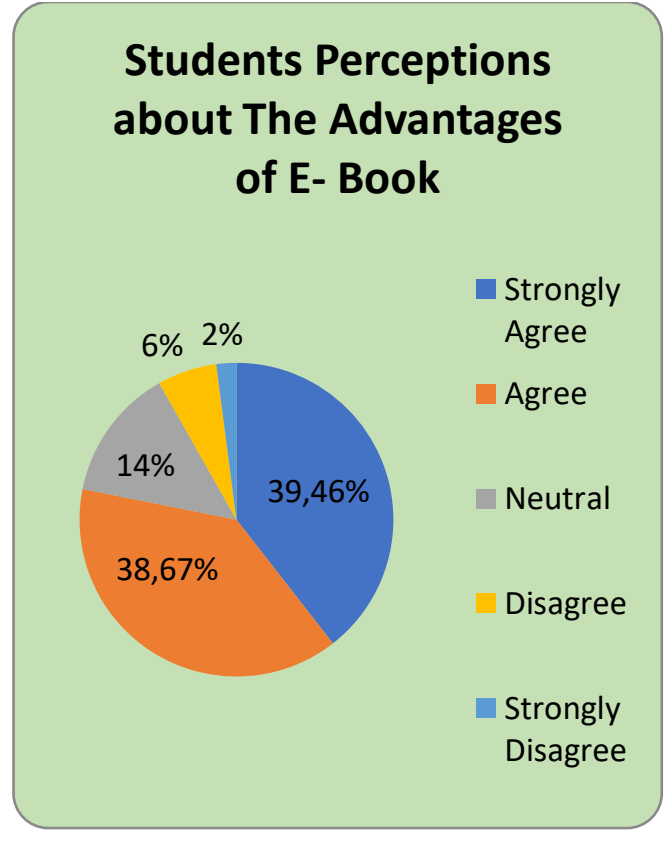

\section{The Result of Questionnaire about the Disadvantages of E- Book}

From the result of finding, it was found that an overwhelming number of students had the disadvantages of E-book. It could be seen from the table 8 , the result of questionnaire (the disadvantages of E-book) in statement 16, 17, 18, 19and 20.

1) Other than that, for item 16,8 students $(36,3 \%)$ answered disagree that they need to purchase E-book before downloading it to their laptop or Smartphone however, 7 students $(31,8 \%)$ choosed strongly disagree with that statement and the others $31,8 \%$ answered neutral.

2) Moreover, for item 17 a high percentage of 13 students (59\%) choosed strongly disagree that they always need to connect to internet 
access before downloading E-book. Likewise, 5 students $(22,7 \%)$ answered disagree, 2 students $(9,10 \%)$ answered neutral with the statement. On the other side, $(2,82 \%)$ of the students answered agree with that statements.

3) In addition, the findings for item 18 show most of the students $(54,5 \%)$ strongly disagree that they need to download a special software in their laptop a Smartphone in order to use Ebook, while 6 students (27\%) disagree and 4 students $(18,2 \%)$ neutral with this statement.

4) As far item 19 is concerned, 13 students (59\%) choosed strongly disagree that just skim reading materials in E-book. While, $(22,7 \%)$ of students answered disagree and $9,10 \%$ of the students answered neutral and agree with this statement.

5) Finally, for item 20, 15 students $(68,1 \%)$ answered strongly disagree that they have little knowledge on how to access and use E-book Then, the other $(27 \%)$ respondents also showed they disagree on this statement, while $4,6 \%$ answered neutral.

Based on finding in this research about students' perception towards the disadvantages of E-book, the researcher found about $82,62 \%$ of the students were strongly disagree, $14,56 \%$ of the students were neutral and $2,82 \%$ of the students were strongly agree and No students agree toward the disadvantages of E-book.

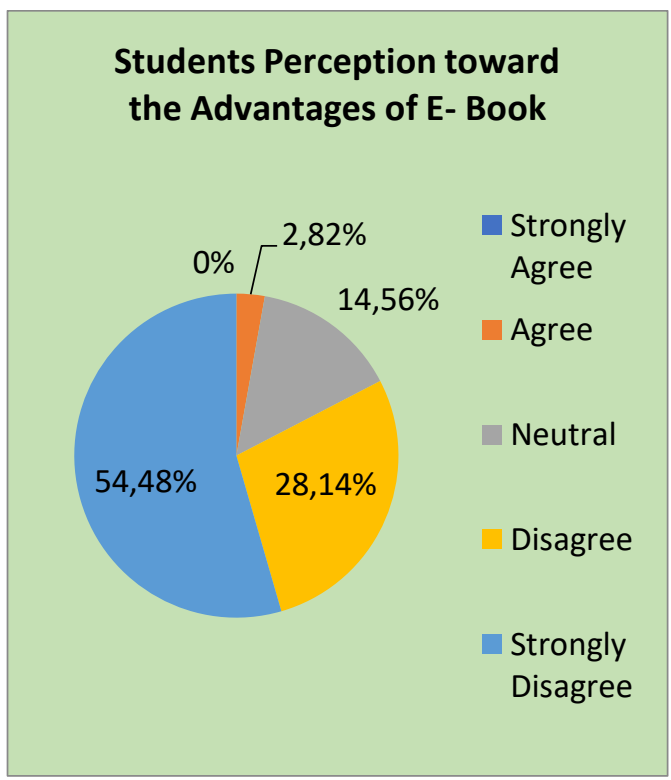

\section{Discussion}

\section{The Result of Students' Perception in} Each Indicator of Questionnaire

\section{a. The use of E-Book in Learning Process}

Based on the result of Students' perception about the use of E-book in Learning Process, the result of findings showed that about $92.90 \%$ of the students choosed strongly agree and agree or had positive response toward the use of E-book in the learning process. This finding was similar with Ningsih (2016) who explained that Ebook was one of technology product in educational life. By using E-book, students can learn how to use technology for their educational supported and students can 
widen their knowledge and creativity by using E-book.

\section{b. The advantages of E-book}

Based on the result of Students' perception about the advantages of Ebook, the result of findings showed that about $78.13 \%$ of the students agreed or had positive response toward the advantages of E-book. The result indicates that the students' response toward the advantages of E-book is positive to support students' learning activities. Ebook is effective learning sources because many reason such as students can bring multiple e-books in their device.

\section{c. The disadvantages of E-book}

Based on the result of students' perception about the disadvantages of using E-book, the research finding showed about $54.48 \%$ of students choosed strongly disagree or had negative response toward the disadvantages of E-book. The result indicates that the students' didn't have problem in using E-book. In short, the use ofE-book can make learning process easier because students can get E- book more easily in internet. By doing so, the students can study by their own.

\section{CONCLUSION}

Based on the findings of the data analysis, the writer concluded that students responded positively and support the use of E-books as learning resources. It demonstrated that the use

E-books as a learning medium is effective. E-books as learning media are simple to use for both lecturer and student. The materials can be found by the students on their own, and lecturers can easily give the students some E-book recommendations that can be used as references in the learning process. Based on the findings, students agree that the E-book is beneficial to their learning process. In addition, E-books are effective learning resources for a variety of reasons, including the ability of students to carry multiple E-books on their device. 


\section{REFERENCES}

Adeyinka, T., \& Dare, O. O., \& Adebisi, O. S., \& Lawal, A. perception and usage pattern of ebooks among library and information science students in seleted universities in Nigeria. Journal of Library \& Information Technology, 38(2).

Chen, Y.L., \& Fan, S., \& He, Z. (2012). Exploratory Research: The Effects of Electronic Books on College Students. MBA Students Scholarship. 14. Retrieved 20

$$
\text { January 2021, from }
$$

(https://scholararchieve.jwu.edu/mba_student/14.

Hadaya, A., \& Asrowi., \& Sunardi. (2018). Perception of Junior High School Students about the Use of E-books as Learning Sources. Journal of Educational Science and Technology. 4(1), 55- 61.

Hasbiyati, H \& Khusnah, L. (2017). The application of e book media extension to increase the interest and learning outcomes of junior high school students on IPA Subject. Journal Pena Saints. 4 (1), 16-21.

Koh, H.S. \& Herring, S.C. (2016). Historical insight for e book design. Library Hi Tech, 34(4), 764-786.

Larson, L.C. (2009). E- reading and e-responding: New tools for generation of readers. Journal of Adolescent and Adult Literacy. 53(3), 255-258.

Majid, Shaheen., \& Chenqin Yu., \& Chang You., \& Zilu, Chen. (2019). Perceptions and Ebook Use Behavior of University Students. International Journal of Digital Society (IJDS), 10(4).

Mulholland, E., \& Bates, J. (2014). Use and perception of e book by academic staff in further education. Journal of Academic Librarianship, 40(5).429-499.

Ningsih, Melya. (2016). Students Perception Toward The Use of E-Book In Learning English at One Public University In Jambi. Undergraduate Thesis, Universitas Jambi.

Sugiyono (2012). Metode penelitian kuantitaif, kualitatif dan $R \& D$. Bandung: Alfabeta.

Walters, W.H. (2014). E-books in academic libraries: Challenges for sharing and use. Journal of Librarianship and Information Science, 46(2) 85-95. DOI:10.1177/0961000612470279.

Wexelbaum, R. S., \& Miltenoff, P., \& Parault, S. J. (2011). E-books and reading comprehension: Perspective of Librarians and Educators. Library Faculty Publications.

Wright, S., Fuget, E., \& Caputa, S. (2013). Using e readers and internet resources to support comprehension. Journal of Educational Technology and Society, 16(1),367-379. 